\title{
Experiences in the assessment of psychosocial risk factors in a cardiovascular rehabilitation clinic- successful implementation of cardiovascular prevention guidelines may increase awareness of psychosocial
}

\section{stressors}

\author{
Márta Germán-Salló',2, Zoltán Prego,2, Enikő Nemes-Nagy³, Dalma Bálint-Szentendrey',2, Tünde Pál4, \\ Károly Csomay'
}

\begin{abstract}
Objectives - To investigate the prevalence of psychosocial risk factors (PRFs) among patients admitted to a cardiovascular rehabilitation clinic. Methods - 43I consecutive inpatients were included. Baseline characteristics and clinical data were extracted from clinical charts. We applied the European Society of Cardiology (ESC) standardized psychosocial questionnaire. Patients were asked about socio-economic status, including education level, work and family stress, social isolation, depression, anxiety, hostility, type $D$ personality, post-traumatic stress disorder, other mental disorders. Results - The mean age was $68 \pm 10$ years, with female predominance $(51.7 \%)$. The most common cardiovascular risk factor was hypertension (94.7\%), mean blood pressure was $136 / 8 \mathrm{I} \mathrm{mmHg}( \pm 20 / \mathrm{II} \mathrm{mmHg})$. The most frequently observed PRFs were social isolation $(72.2 \%)$, low socio-economic status $(63.8 \%)$, work stress $(65.2 \%)$ and hostility $(65.9 \%)$. Social isolation $(p=0.0034)$, depression $(p<0.000 \mathrm{I})$, anxiety $(p<0.000 \mathrm{I})$, hostility $(p=0.0438)$, type $D$ personality $(p<0.000 \mathrm{I})$, post-traumatic stress disorders $(p=0.0004)$ and other mental disorders $(p=0.0350)$ were more frequent in women. Men suffered significantly more frequent from work stress $(p=0.0409)$. Conclusions - PRFs are common among patients with CVD with significant gender differences. Screening for PRFs can easily be performed. Identification of affective disorders and other chronic stressors may have an impact on future cardiovascular events and on treatment adherence.
\end{abstract}

Keywords: cardiovascular diseases, psychosocial risk factors, cardiovascular prevention, classical risk factors.

Rezumat: Obiectiv - Evaluarea prevalenței factorilor de risc psihosociali într-o clinică de recuperare cardiovasculară. Metode - Am inclus consecutiv 43I de pacienți internați în această clinică. Caracteristicile de bază și datele clinice au fost extrase din foile de observații. Am utilizat chestionarul psiho-social standardizat, recomandat de Societatea Europeană de Cardiologie. Pacienții au fost chestionați asupra statusului socio-economic, inclusiv nivelul de educație, stresului de la servici și în viața de familie, lipsei de sprijin social, depresiei, anxietății, ostilității, personalității de tip D, stresului post-traumatic și asupra altor afecțiuni psihiatrice. Rezultate - Vârsta medie a fost de $68 \pm 10$ ani, cu predominanța femeilor (5I,7\%). Cel mai frecvent factor de risc cardiovascular a fost hipertensiunea arterială (94,7\%), tensiunea arterială medie a fost $136 / 8 \mathrm{I} \mathrm{mmHg}$ $(20 / 1 \mathrm{l} \mathrm{mmHg})$. Factorii psihosociali cei mai des întâlniți în studiul nostru au fost absența sprijinului social (72,2\%), statusul socio-economic precar $(63,8 \%)$, stresul ocupațional $(65,2 \%)$ și ostilitatea $(65.9 \%)$. Absența spirjinului social $(p=0,0034)$, depresia $(p<0.000 \mathrm{I})$, anxietatea $(p<0,000 \mathrm{I})$, ostilitatea $(p=0,0438)$, personalitatea de tip $D(p<0,000 \mathrm{I})$, stresul post-traumatic $(p=0,0004)$ și alte afecțiuni psihiatrice $(p=0,0350)$ au fost mai frecvent întâlnite la femei. Bărbații au fost mai des expuși stresului ocupațional $(p=0.0409)$. Concluzii - Factorii de risc psihosociali sunt frecvent prezenți la pacienții cu boli cardiovasculare existând diferențe semnificative între sexe. Screeningul lor se poate efectua cu ușurință. Identificarea tulburărilor afective și a altor stresori cronici psihosociali pot avea un impact asupra dezvoltării, prognosticului bolilor cardiovasculare și asupra aderenței la tratament.

Cuvinte cheie: boli cardiovasculare, factori de risc psihosocial, prevenție cardiovasculară, factori de risc tradiționali.

\footnotetext{
' „George Emil Palade” University of Medicine, Pharmacy, Science and Technology, Targu Mures, Romania

${ }^{2}$ Department of Cardiovascular Rehabilitation, Emergency Clinical County Hospital, Targu Mures, Romania

${ }^{3}$ Department of Fundamental Pharmaceutical Sciences, ,George Emil Palade" University of Medicine, Pharmacy, Science and Technology,

Targu Mures, Romania

${ }^{4}$ Emergency Institute for Cardiovascular Diseases and Transplantation,

Targu Mures, Romania
}

\author{
$\checkmark$ Contact address: \\ Zoltán Preg, MD \\ Department of Cardiovascular Rehabilitation, Emergency Clinical \\ County Hospital, Targu Mures, Romania. \\ E-mail: preg_zoltan@hotmail.com
}




\section{List of abbreviations used in text \\ CVD cardiovascular disease \\ ESC European Society of Cardiology \\ PAD peripheral artery disease \\ CHD coronary heart disease \\ PRFs psychosocial risk factors \\ HTN arterial hypertension \\ SBP systolic blood pressure \\ DBP dyastolic blood pressure \\ BMI body mass index \\ MI myocardial infarction \\ CABG coronary artery bypass graft \\ $\mathrm{PCl}$ percutaneous coronary intervention \\ BDI- 13 Beck Depression Inventory- 13 item form \\ PTSD post-traumatic stress disorder}

\section{INTRODUCTION}

The prevalence of cardiovascular diseases (CVD) according to a survey which included member countries of the European Society of Cardiology (ESC) was approximately 83.5 million in 2015'. Peripheral artery disease (PAD) was at the top of the list ( 35.7 million) followed by coronary heart disease (CHD) (29.4 million)'. CVD are the leading cause of mortality and morbidity, being responsible for around $45 \%$ of all deaths in Europe ${ }^{2}$, with a higher mortality rate in Central and Eastern Europe ${ }^{2}$. Data suggest, no change is predicted in the near future, due to the aging and growing of the population. There is a worldwide variation in the incidence CVD with a higher burden in low and middleincome countries ${ }^{3}$.

Traditional risk factors do not fully explain the CVD risk in populations, and there is increasing awareness of the impact of social environment and psychological factors on CVD incidence and outcomes. The measurement of psychosocial variables is uniquely complex as variables are difficult to define objectively ${ }^{4}$. Risk factors related to an increased risk of development of CVD were firstly mentioned in studies derived from the Framingham Heart Study ${ }^{5}$. High blood pressure and high cholesterol level were found to be associated with cardiovascular risk and outcomes ${ }^{6}$. Additionally, the same study, demonstrated the promoting role of other risk factors in cardiovascular diseases, like diabetes mellitus, smoking, physical inactivity and obesity $^{5}$. These are recognized as classical cardiovascular risk factors. Cardiovascular disease mostly develops in those who are exposed to at least one of these hazards. Noteworthy, they are easily quantifiable and influencing them has been for a long time the core action in cardiovascular prevention and rehabilitation.
Lately, besides traditional cardiovascular risk factors, the role of individual psychosocial risk profile in CVD development came into the spotlights. Emerging data show the causative or intermediate effect of psychosocial risk factors (PRFs), classified as emotional factors such as depression, anxiety, anger, hostility and chronic stressors including low socioeconomic status, low social support, work stress, marital stress and caregiver strain ${ }^{7-9}$ in relationship with CVDs. The role of PRFs in cardiovascular diseases mainly was investigated in relation with the burden and prognosis of coronary heart disease ${ }^{10-12}$, heart failure and arrhythmias $^{13}$. In a recent review Rozanski reports, that despite this growing knowledge, translation into clinical cardiology did not become a practice ${ }^{14}$.

The current 2016 European Guidelines on CVD prevention tries to overcome this problem. According to it, assessment of PRFs could be important, as these play a role in the development and prognosis of CVD and also have an impact on lifestyle and treatment adherence $^{15}$. The use of standardized questionnaires or clinical interviews should be considered (class of recommendation IIA; level of evidence B) in high CVD risk patients based on total CVD risk assessed by SCORE chart or in patients already diagnosed with CVD $^{15}$. Currently, there is insufficient data to support the routine assessment of these factors ${ }^{15}$. However, there is growing evidence, that psychosocial risk profile identification may have positive influence on cardiovascular disease progression. In any case, despite recommendations, implementation of guideline is frequently lacking in everyday practice.

The aim of this study was to investigate psychosocial risk factors among patients in a cardiovascular rehabilitation clinic. Using a standardized questionnaire proposed by ESC prevention team, we also try to show, that implementation of guidelines recommendations is achievable ${ }^{15}$.

\section{METHODS}

This cross-sectional study was conducted at the Târgu Mureș Cardiovascular Rehabilitation Department. A total number of 431 patients were included. All participants underwent general physical examination, height, weight and blood pressure measurement. We recorded socioeconomic and demographic data, clinical data including personal and family history of comorbidities and cardiovascular risk factors. Routine laboratory investigations (complete blood count, glycaemia, full lipid profile, creatinine, uric acid, liver 
enzymes, and urine sample) were done in every patient, as well as ECG and cardiac ultrasound. Other paraclinical investigations were completed according to each patient's disease profile.

Each participant enrolled in the study filled in the standardized self-administered psychosocial questionnaire on mother tongue (Romanian or Hungarian). To be mentioned that this was administered irrespective of the 10 year cardiovascular SCORE risk chart (this was evaluated only in patients with no manifest cardiovascular disease). The questionnaire consisted of nineteen items in nine topics: low socio-economic status (also one question with respect to education level, divided into six categories: ${ }^{\text {st }}$ category (C): I-4 classes, $2^{\text {nd }}$ C: $5-8$ classes, $3^{\text {rd }}$ C: Gymnasium, 4th C: Professional school, $5^{\text {th }}$ C: Vocational school, 6th C: University), work and family stress, social isolation, depression, anxiety, hostility, type D personality, post-traumatic stress disorder and other mental disorders ${ }^{15}$. This form is slightly extended compared to the version recommended in the 2012 European guidelines on the prevention of CVD in clinical practice ${ }^{16}$. In addition most of patients completed the shortened 13-item form Beck Depression Inventory.

The Ethics Committee of the Emergency County Clinical Hospital of Targu Mures approved the study and patients signed a consent form to participate in our research study.

Microsoft Office Excel was used for data input and statistical software SPSS v.20.0 for data management and analyses. Descriptive statistics were performed for variables and expressed as mean $\pm S D$ and frequency (\%) for categorical variables.

\section{RESULTS}

\begin{tabular}{|l|c|c|}
\hline \multicolumn{3}{|l|}{ Table I. Education level } \\
\hline & N & $\%$ \\
\hline I-4 classes & 12 & $2.9 \%$ \\
\hline $5-8$ classes & 120 & $28.6 \%$ \\
\hline Gymnasium & 101 & $24.0 \%$ \\
\hline Professional school & 94 & $21.8 \%$ \\
\hline Vocational school & 94 & $22.4 \%$ \\
\hline University & 53 & $12.6 \%$ \\
\hline
\end{tabular}

The study analyzed data for $43 \mathrm{I}$ patients, ranged from 37 to 93 years, mean age $68 \pm 10$ years. The majority of the participants were females $51.7 \%(n=223), 51.6 \%$ of patients came from rural environment. Most of them had attained gymnasium $24.0 \%(n=10 I)$ and classes from five to eight $28.6 \%(n=120)$, a significant proportion of the participants had professional education
Psychosocial risk factor assessment in cardiovascular patients

$21.8 \%(n=94)$ and only $12.6 \%(n=53)$ had a university degree (Table I).

The most common classical cardiovascular risk factor was arterial hypertension (HTN) (already diagnosed and treated or newly diagnosed), $94.7 \%(n=408)$ of the patients had different grades of HTN. The majority of the participants had second grade HTN $60.1 \%(n=259)$, and $74.5 \%(n=321)$ with very high additional cardiovascular risk. Overall mean blood pressure under antihypertensive therapy was 136/8I $\mathrm{mmHg}( \pm 20 / \mathrm{II} \mathrm{mmHg})$. Hypercholesterolemia was detected in $33.1 \%(n=143)$. Disorders in glucose homeostasis were observed in almost half of the cases $48.1 \%(n=207)$ with the predominance of type 2 diabetes $38.3 \%(n=165)$. Obesity was present in $53.59 \%$ $(n=231)$, the most common was grade one obesity $32.7 I \%(n=|4|)$ and overall mean BMI was $31.05 \pm 6$. I I

\begin{tabular}{|c|c|c|}
\hline & N/Mean & $\% / S D$ \\
\hline Participants & $43 I$ & $100.00 \%$ \\
\hline Age (y) & 67.69 & 9.92 \\
\hline \multicolumn{3}{|l|}{ Sex } \\
\hline Female & 223 & $51.7 \%$ \\
\hline Male & 208 & $48.3 \%$ \\
\hline \multicolumn{3}{|l|}{ Proveniance } \\
\hline Urban & & $48.4 \%$ \\
\hline Rural & & $51.6 \%$ \\
\hline Heart rate (bpm) & 71.84 & $14.7 \mid$ \\
\hline Hypertension & 408 & $94.70 \%$ \\
\hline HTN Grade I & 12 & $2.8 \%$ \\
\hline HTN Grade II & 259 & $60.10 \%$ \\
\hline HTN Grade III & 137 & $31.80 \%$ \\
\hline Mean SBP/DBP $(\mathrm{mmHg})$ & $|36 / 8|$ & $20 / 11$ \\
\hline Total cholesterol $(\mathrm{mmol} / \mathrm{L})$ & 4.71 & 1.24 \\
\hline Hypercholesterolemia (>190 mg/dl) & 143 & $33.1 \%$ \\
\hline \multicolumn{3}{|l|}{ Glucose homeostasis } \\
\hline Diabetes type 2 & 165 & $38.3 \%$ \\
\hline Diabetes type I & 2 & $0.5 \%$ \\
\hline Impaired fasting glucose & 13 & $3.0 \%$ \\
\hline Impaired glucose tolerance & 27 & $6.3 \%$ \\
\hline Mean BMI $\left(\mathrm{kg} / \mathrm{m}^{2}\right)$ & 31.05 & 6.11 \\
\hline Obesity & 231 & $53.59 \%$ \\
\hline Mean BMI $\left(\mathrm{kg} / \mathrm{m}^{2}\right)$ & 35.32 & 4.83 \\
\hline Obesity Grade I & $14 \mid$ & $32.71 \%$ \\
\hline Obesity Grade II & 54 & $12.52 \%$ \\
\hline Obesity Grade III & 36 & $8.35 \%$ \\
\hline \multicolumn{3}{|l|}{ Comorbidities } \\
\hline Coronary heart disease (all) & 160 & $37.1 \%$ \\
\hline Previous $\mathrm{Ml}$ & 40 & $9.2 \%$ \\
\hline CABG & 17 & $3.9 \%$ \\
\hline $\mathrm{PCl} \pm$ Stenting & 20 & $4.6 \%$ \\
\hline Cerebrovascular disease & 53 & $12.2 \%$ \\
\hline Peripheral artery disease & 69 & $16.0 \%$ \\
\hline Atrial fibrillation & 107 & $24.8 \%$ \\
\hline
\end{tabular}




\begin{tabular}{|c|c|c|c|c|}
\hline Psychosocial risk factors & Total sample & Females \% (n) & Males \% (n) & P-value \\
\hline Low socio-economic status & $63.8(275)$ & $67.3(150)$ & $60.1(125)$ & 0.1736 \\
\hline Work stress & $65.2(28 I)$ & $61.4(137)$ & $69.2(144)$ & 0.0409 \\
\hline Family stress & $10.7(46)$ & $12.1(27)$ & $9.1(19)$ & 0.2744 \\
\hline Social isolation & $72.2(3 \mathrm{II})$ & $79.8(178)$ & $63.9(133)$ & 0.0034 \\
\hline Depression & $31.6(136)$ & $43.9(98)$ & $18.3(38)$ & $<0.0001$ \\
\hline Anxiety & $45.2(195)$ & $58.3(130)$ & $31.3(65)$ & $<0.0001$ \\
\hline Hostility & $65.9(284)$ & $70.0(156)$ & $61.5(128)$ & 0.0438 \\
\hline Type D personality & $55.5(239)$ & $64.1(143)$ & $46.2(96)$ & $<0.0001$ \\
\hline Post-traumatic stress disorder & $57.3(247)$ & $65.5(146)$ & $48.6(101)$ & 0.0004 \\
\hline Other mental disorders & $8.8(38)$ & $11.2(25)$ & $6.3(13)$ & 0.0350 \\
\hline
\end{tabular}

$\mathrm{kg} / \mathrm{m}^{2}$ and $29.5 \%(\mathrm{n}=127)$ of the enrolled patients had normal weight (Table 2).

In our study, the most frequent psychosocial factors were social isolation (72.2\%), low socio-economic status $(63.8 \%)$, work stress $(65.2 \%)$ and hostility (65.9\%). Gender-related significant difference was detected in the presence of psychosocial risk factors. Social isolation $(p=0.0034)$, depression $(p<0.000 \mathrm{I})$, anxiety $(p<0.000 \mathrm{I})$, hostility $(p=0.0438)$, type $D$ personality $(p<0.000 \mathrm{I})$, post-traumatic stress disorders $(p=0.0004)$ and other mental disorders $(p=0.0350)$ were more frequent by women. While men significantly more frequently suffered from work stress $(p=0.0409)$ compared to women. The prevalence of low socio-economic status and family stress did not differ between sexes in our study. Depression was present in $31.6 \%$. However, after $83 \%$ of the patients $(n=359)$ completed the shortened I3-items form Beck Depression Inventory (BDI- I3) this increased to $46.63 \%(n=201)$. Mild depression was present in $29.7 \%$ $(n=128)$, moderate in $8.6 \%(n=37)$ and severe depression in $8.4 \%(n=36)$ of the participants (Table 3$)$.

Psychosocial stress factors usually appear in association with each other (Table 4). In this paper approx. in $17 \%$ from three to five psychosocial factors were present in the same individual.

\section{DISCUSSION}

Psychosocial risk factors are highly prevalent in cardiovascular illnesses. Emerging data suggest, they do have a role in the etiology of the disease, may promote progression and also could be a barrier to treatment adherence. The INTERHEART case-control trial (conducted in 52 countries) offers a larger perspective on the global evaluation of coronary artery disease risk factors ${ }^{10}$. The study concluded that nine cardiovascular risk factors, including traditional cardiovascular risk factors completed with PRFs, are deemed for more

\begin{tabular}{|l|c|c|}
\hline \multicolumn{3}{|l|}{ Table 4. Number of associated factors } \\
\hline & N & Percent $\%$ \\
\hline 0 & 6 & 1.4 \\
\hline 1 & 22 & 5.1 \\
\hline 2 & 35 & 8.1 \\
\hline 3 & 73 & 16.9 \\
\hline 4 & 72 & 16.7 \\
\hline 5 & 75 & 17.4 \\
\hline 6 & 57 & 13.2 \\
\hline 7 & 45 & 10.4 \\
\hline 8 & 37 & 8.6 \\
\hline 9 & 9 & 2.1 \\
\hline Total & 431 & $100.0 \%$ \\
\hline
\end{tabular}

than $90 \%$ of the risk for acute myocardial infarction ${ }^{10}$. Smoking and hyperlipidemia were the most strongly related to the acute event followed by psychosocial factors, abdominal obesity, diabetes and hypertension ". Interestingly, current evidence from the literature suggest, that PRFs may also have a role in promoting other major cardiovascular risk factors like hypertension or diabetes mellitus ${ }^{4}$. The relationship between PRFs and stroke have been also largely evaluated in several studies, like Interstroke and Copenhagen City Heart Study, showing that risk of stroke is increased in the presence of psychosocial stressors ${ }^{10,17}$. Despite these findings, influence of PRFs on CVDs is still underestimated in comparison to traditional risk factors.

Therefore, integrating psychosocial risk profile evaluation into cardiology practice is becoming an urgent need. This study shows our experiences in the screening of psychosocial risk factors. In comparison to traditional cardiovascular risk factors these are less easily quantifiable and more subjective, as they are based on self-report. However, the standardized psychosocial risk assessment tool recommended by the ESC could be easily administered in our patients admitted to the cardiovascular rehabilitation clinic. Based upon the answers obtained during the self-administered questi- 
onnaire we were able to identify affective disorders (depression, anxiety), personality traits (hostility, Dtype personality) as well as chronic stressors like low socio-economic status, social isolation, marital and work related stress.

Low social status is measured by education degree and family income and it is related to the development of $\mathrm{CHD}^{18}$ and $\mathrm{CHD}$ mortality ${ }^{19}$ and also with poor prognosis in CVD ${ }^{20}$. More than half of our study population fell into the category of low social status. Family stress was less frequently encountered among our patients. In general population being unmarried, independently of gender, is related to a higher incidence of CHD and cardiac mortality ${ }^{21}$. Studies suggest that being married facilitates a healthy behavior and lifestyle, adherence to treatment, the recognition of symptoms in heart failure ${ }^{22}$.

Work stress including high job demands, low control at work, long working hours are widely investigated in CHD. According to a large meta-analysis, there is unequivocal association between job strain and CVD risk ${ }^{23}$. The largest case-control trial in this field demonstrates that work stress is associated with a doubled risk of CHD and it is more important in men than in women". Our results also show a significantly higher prevalence of work stress among men compared to women. Overall more than half of the inquired patients reported stress related to work. According to a recent cohort study, long working hours also increase stroke risk ${ }^{24}$.

Data from the literature are consistent regarding the association of depression and heart disease. Future projections of the $\mathrm{WHO}$ places depression as a second cause of disability in developed countries, just after CVDs ${ }^{25}$. Depression is considered an independent risk factor related to the incidence and prognosis of $\mathrm{CHD}^{26}$. It is also proved to be common among survivors of acute cardiac events ${ }^{27}$. Patients with depression are less likely to adhere to secondary preventive measures like quitting smoking, eating healthy or being physically active. The findings of the EUROASPIRE IV survey also support this statement and connect this negative emotional factor to other cardiovascular risk factors, such as current smoking, central obesity and diabetes $^{28}$. Furthermore, as shown in a meta-analysis conducted by Pan and collaborators, depression is also linked to stroke risk ${ }^{29}$. We found depression in almost half of our patients, with a female predominance. Mild and moderate forms were more frequent. One third of the cases were revealed only, when Beck Depression Inventory was administered.
Besides depression, anxiety is another negative emotion proved to be an independent risk factor for CHD and cardiac mortality. This connection is less strong in comparison to the that of depression, on the other hand is stronger when compared to anger ${ }^{30}$. In our study prevalence of anxiety was comparable to that of depression and was also more frequent in women. Undoubtedly, the overlapping of anxiety and depression may strengthen the emotional distress of these individuals. Data from the national SWEDEHEART registers showed that in patients after a myocardial infarction cardiovascular and general mortality are both increased if symptoms of anxiety and depression are constantly present ${ }^{31}$. With almost every second patient being anxious, our results showed a higher prevalence when compared to $30-40 \%$ found in a systematic review ${ }^{30}$. Evidently, the different anxiety evaluation method can explain this finding.

With respect to hostility and anger Chida and collaborators stated in a meta-analytic review of prospective cohort studies, that these negative traits are linked to enhanced rate of events both in healthy subjects and those with established $\mathrm{CHD}^{30}$. Furthermore, they may increase the likelihood of recurrence ${ }^{30}$. Interestingly, connection of anger and hostility to CHD events was stronger in healthy men compared to women $^{32}$. Opposite to this, hostility was more frequent in our female patients. However, overall this was the second most prevalent psychosocial risk factor among our patients. Anger is also related to increased cardiac mortality and poor prognosis in patients with $\mathrm{CHD}^{32}$.

Type $D$ personality defines a high level of negative thoughts and emotions. It appears in one-third of individuals with $\mathrm{CVD}^{33}$. We demonstrated a much higher incidence, more than half of our patients confessed negative emotions, with female predominance.

Post-traumatic stress disorder (PTSD) is a reaction caused by a life-threatening event (like myocardial infarction) making a person to become anxious, frightened, helpless, frequently affecting his daily functioning. It is a negative emotional state in which individuals may re-live the traumatic event, avoid reminders and have negative thoughts and feelings. Prevalence of PTSD is high among patients with cardiac diseases, appears more frequently in women and is responsible for higher mortality ${ }^{34}$. Our study is consistent with these findings, as we found PTSD in more than half of the patients, with female predominance.

The THORESCl study, a prevalence study in coronary heart disease patients from the Netherlands used 
the same questionnaire applied in our study showing a better psychosocial profile of their patients: social isolation $28 \%$ vs. $72 \%$, depression $24 \%$ vs. $31.6 \%$, hostility $53 \%$ vs. $65.9 \%$, type D personality $50 \%$ vs. $55.5 \%$, with a slightly less prevalent anxiety in our patients $48 \%$ vs. $45.2 \%$.

Psychosocial risk factors are often related to each other and their effects are cumulative which may increase the rate of cardiovascular events. The risk of CVD owed to the combination of these factors in some studies was similar to the risk associated to CHD traditional risk factors, such as hypertension, hypercholesterolemia ${ }^{36}$. For instance, chronic stress at work is related to increased incidence of depression $^{37}$, and both can promote ischemic heart disease ${ }^{38,39}$. Furthermore, low socioeconomic status was observed to accompany social isolation and depression ${ }^{33}$. We observed in our study clustering of three to five PRFs which may enhance global health risk.

The association of traditional cardiovascular risk factors with PRFs was not evaluated in this work. However, according to the literature there is convincing data supporting the existence of a relationship between PRFs and traditional risk factors, such as hypertension, hypercholesterolemia, smoking, diabetes, obesity and physical inactivity ${ }^{13,34}$. For instance, in acute stressful events blood pressure increases transiently. Moreover, a higher incidence of hypertension associated with the presence of chronic stressors was observed, in particular if the stress managing response was altered due to depression or anxiety ${ }^{40}$. Association of PRFs with unhealthy behavior (sedentary lifestyle, alcohol and tobacco use, poor diet) is also well documented, as well as their negative influence on treatment adherence. Overall, a broad spectrum of biological, psychological and social variables, seem to act synergistically resulting in increased CV morbidity and mortality.

Cardiologist and general physician can easily take measures for the assessment of PRFs while taking medical history with simple questions or using standardized questionnaires. In special cases, when it is necessary they need to refer the patient for further investigations and special treatment. Interventions to the decrease psychosocial hazard include individualized recommendations regarding education, and physical activity, promoting healthy behaviors, relaxation methods, stress management ${ }^{13,33}$. In special cases, like patients with clinically severe symptoms, psycho- and pharmacotherapy, coordinated by a specialist might be needed ${ }^{13}$. It is unanimously accepted that exercise is beneficial for the prevention of CHD, but it was also demonstrated that may reduce the incidence of depression ${ }^{7}$.

The limitation of the present study includes that we did the research on consecutive inpatients, independently of the results of SCORE risk chart. In addition, a great proportion of enrolled patients were pensioners, a part of them missed to answer the following questions: „Are you a manual worker”; ,Do you lack control over how to meet the demands at work?"; „Is your reward inappropriate for your effort?", which imply bias on the interpretation of the first two psychosocial factors. Also, the results for depressive status are questionable, as the presence of depression according to the $\mathrm{BD}^{1-13}$ test was double compared to the prevalence obtained with the psychosocial questionnaire. Furthermore, independent variables were not investigated in our study.

Besides focusing on traditional cardiovascular risk factors and their prevention, physicians should be aware of the presence and effect of novel cardiovascular risk factors, such as psychosocial domains. Early detection and treatment of emotional and behavioral disturbances may attenuate the incidence of CVD events, treatment adherence, and quality of life.

\section{CONCLUSION}

Overall, this paper presents the results of a survey on psychosocial risk factors among patients with CVD. The present findings confirm that PRFs are common in patients with CVD and also suggest gender differences in the prevalence of PRFs. Findings highlight the need to raise the awareness of these non-traditional risk factors and also show that screening for them can easily be performed. Further research is required to elucidate whether addressing these psychosocial attributes and integrating them in global cardiovascular risk assessment and cardiovascular rehabilitation programs will be able to change the course of the CVD along the cardiovascular continuum.

\section{Conflict of interest: none declared.}

\section{References}

I. Timmis A, Townsend N, Gale C, Grobbee R, Maniadakis N, Flather M, Wilkins E, Wright L, Vos R, Bax J, Blum M, Pinto F, Vardas P. European Society of Cardiology: Cardiovascular disease statistics 2017. Eur Heart J 2018;39: 508-577

2. Wilkins E, Wilson L, Wickramasinghe K, Bhatnagar P, Leal J, LuengoFernandez R, Burns R, Rayner M, Townsend N. European cardiovascular disease statistics 2017. Eur Hear Network 2017;192.

3. Thomas H, Diamondy J, Viecoy A, Chaudhuriy S, Shinnary E, Crom- 
ery S, Perelz P, Mensahk GA, Narula J, Johnson CO, Roth GA, Moran AE. Global Atlas of Cardiovascular Disease 2000-2016: The path to prevention and control. Glob Heart 2018; 13: 143-163.

4. Neylon A, Canniffe C, Anand S, Kreatsoulas C, Blake GJ, Sugrue D, McGorrian C. A global perspective on psychosocial risk factors for cardiovascular disease. Prog Cardiovasc Dis 2013;55: 574-58I.

5. Kannel WB, Dawber TR, Kagan A, Revotskie N, Stokes J. Factors of risk in the development of coronary heart disease-six year follow-up experience. The Framingham Study. Ann Intern Med I961;55: 33-50.

6. Donnell CJO, Elosua R. Cardiovascular risk factors. Insights from Framingham Heart Study. Rev Esp Cardiol 2008;61: 299-310.

7. Rozanski A, Blumenthal JA, Davidson KW, Saab PG, Kubzansky L. The epidemiology, pathophysiology, and management of psychosocial risk factors in cardiac practice. The emerging field of behavioral cardiology. J Am Coll Cardiol 2005;45: 637-65I.

8. Tillmann T, Pikhart H, Peasey A, Kubinova R, Pajak A, Tamosiunas A, Malyutina S, Steptoe A, Kivimaki M, Marmot M, Bobak M. Psychosocial and socioeconomic determinants of cardiovascular mortality in Eastern Europe: A multicentre prospective cohort study. PloS Med 2017;14: I-20.

9. Albert MA, Glynn RJ, Buring J, Ridker PM. Impact of traditional and Novel Risk Factors on the Cardiovascular Events. Circulation 2006; 12: 2619-2626.

10. Schnohr P, Marott JL, Kristensen TS, Gyntelberg F, Gronbaek M, Lange $P$, Jensen $M T$, Jensen GB, Prescott E. Ranking of psychosocial and traditional risk factors by importance for coronary heart disease: the Copenhagen City Heart Study. Eur Heart J 2015;36: 13851393.

II. Yusuf S, Hawken S, Ounpuu S, Dans T, Avezum A, Lanas F, McQueen M, Budaj A, Pais P, Varigos J, Lisheng L. Effect of potentially modifiable risk factors associated with myocardial infarction in 52 countries (the INTERHEART study): case-control study. Lancet 2004;364: 937-952.

12. Schnohr P, Jensen JS, Scharling $H$, Nordestgaard BG. Coronary heart disease risk factors ranked by importance for the individual and community A 21 year follow-up of 12000 men and women from The Copenhagen City Heart Study. Eur Heart J 2002;23: 620-626.

13. Ladwig KH, Lederbogen F, Albus C, Angermann C, Borggrefe M, Fischer D, Fritzsche K, Haass M, Jordan J, Junger J, Kindermann I, Kollner V, Kuhn B, Scherer M, Seyfarth M, Voller H, Waller C, Hermann-Lingen $C$. Position paper on the importance of psychosocial factors in cardiology: Update 2013 Positionspapier zur Bedeutung psychosozialer Faktoren in der Kardiologie: Update 2013. GMS German medical Science 2014;12: I-24.

14. Rozanski A. Behavioral cardiology: Current advances and future directions. J Am Coll Cardiol 2014;64: 100-II0.

15. Piepoli M, Hoes AW, Agewall S, Albus C, Brotons C, Catapano AL, Cooney MT, Corra U, Cosyns B, Deaton C, Graham I, Hall MS, Hobbs FDR, Lochen ML, Lollgen H, Marques-Vidal P, Perk J, Prescott E, Redon J, Richter DJ, Sattar N, Smulders Y, Tiberi M, Bart van der Worp H, van Dis I, Verschuren WMM. 2016 European Guidelines on cardiovascular disease prevention in clinical practice The Sixth Joint Task Force of the European Society of Cardiology. Eur Heart J 2016;37: 23I5-238I.

16. Perk J, De Backer G, Gohlke H, Graham I, Reiner Z, Verschuren WMM, Albus C, Benlian P, Boysen G, Cifkova R, Deaton C, Ebrahim S, Fisher M, Germano G, Hobbs R, Hoes A, Karadeniz S, Mezzani A, Prescott E, Ryden L, Scherer M, Syvanne M, Scholte WJM, Reimer O, Vrints C, Wood D, Zamorano JL, Zannad F. European guidelines on cardiovascular disease prevention in clinical practice (version 2012): The fifth joint task force of the European society of cardiology and other societies on cardiovascular disease prevention in clinical practice (constituted by representatives of nine societies and by invited experts). Eur heart J 20I2; 19: 403-488.

17. O'Donnell MJ, Xavier D, Liu L, Zhang H, Chin SL, Rao-Melacini P, Rangarajan S, qul Islam S, Pais P, McQueen MJ, Mondo C, Damasceno A, Lopez-Jaramillo P, Hankey GJ, Dans AL, Yusoff K, Truelsen T, Diener HC, Sacco RL, Ryglewicz D, Czlonkowska A, Weimar C, Wang $X$, Yusuf S. Risk factors for ischaemic and intracerebral haem-
Psychosocial risk factor assessment in cardiovascular patients

orrhagic stroke in 22 countries (the INTERSTROKE study): A casecontrol study. Lancet 2010; 376: II2-123.

18. Valtorta K, Kanaan M, Gilbody S, Ronzi S, Hanratty B. Loneliness and social isolation as risk factors for coronary heart disease and stroke: Systematic review and meta-analysis of longitudinal observational studies. Heart 2016;0: I-8.

19. Woodward M, Brindle P, Tunstall-Pedoe H. Adding social deprivation and family history to cardiovascular risk assessment: the ASSIGN score from the Scottish Heart Health Extended Cohort (SHHEC). Heart 2007;93: 172-176.

20. Barth J, Schneider S, von Kanel R. Lack of social support in the etiology and the prognosis of coronary heart disease: A systematic review and meta-analysis. Psychosom Med 2010;72: 229-238.

21. Wong CW, Kwok CS, Narain A, Gulati M, Mihalidou AS, Wu P, Alasnag M, Mynt PK, Mamas MA. Marital status and risk of cardiovascular diseases: a systematic review and meta-analysis. Heart 2018;104: 1937-1948.

22. Wu JR, Lennie TA, Chung ML, Frazier SK, Dekker RL, Biddle MJ, Moser DK. Medication adherence mediates the relationship between marital status and cardiac event-free survival in patients with heart failure. Heart Lung 2012;83: I07-I I4.

23. Kivimaki M, Nyberg ST, Batty GD, Fransson El, Heikkila K, Alfredsson L, Bjorner JB, Borritz M, Burr H, Casini A, Clays E, De Bacquer D, Dragano N, Ferrie JE, Geuskens GA, Goldberg M, Hamer M, Hooftman WE, Houtman IL, Joensuu M, Jokela M, Kittel F, Knutsson A, Koskenvuo M, Koskinen A, Kouvonen A, Kumari M, Madsen IEH, Marmot MG, Nielsen ML, Nordin M, Oksanen T, Pentti J, Rugulies R, Salo P, Siegrist J, Singh-Manoux A, Suominen SB, Vaananen A, Vahtera J, Virtanen M, Westerholm PMJ, Westerlund H, Zins M, Steptoe A, Theorell T. Job strain as a risk factor for coronary heart disease: a collaborative meta-analysis of individual participant data. Lancet 2012;380: |49|-1497.

24. Fadel M, Sembajwe G, Gagliardi D, Pico F, Li J, Ozguler A, Siegrist J, Evanoff BA, Baer M, Tsutsumi A, lavicoli S, Leclerc A, Roquelaure $Y$, Descatha A. Association between reported long working hours and history of stroke in the CONSTANCES Cohort. Stroke 2019;50: 1879-1882.

25. Murray CJ, Lopez AD. Global mortality, disability, and the contribution of risk factors: Global Burden of Disease Study. Lancet 1997;349: |436-|442.

26. Nicholson $\mathrm{A}$, Kuper $\mathrm{H}$, Hemingway $\mathrm{H}$. Depression as an aetiologic and prognostic factor in coronary heart disease: A meta-analysis of 6362 events among 146538 participants in 54 observational studies. Eur Heart J 2006;27: 2763-2774.

27. Thombs BD, Bass EB, Ford DE, Stewart KJ, Tsilidis KK, Patel U, Fauerbach JA, Bush DE, Ziegelstein RC. Prevalence of depression in survivors of acute myocardial infarction review of the evidence. J Gen Intern Med 2006;21: 30-38.

28. Pogosova N, Kotseva K, De Bacquer D, Von Kanel R, De Smedt $D$, Bruthans J, Dolzhenko M. Psychosocial risk factors in relation to other cardiovascular risk factors in coronary heart disease: Results from the EUROASPIRE IV survey. A registry from the European Society of Cardiology. Eur J Prev Cardiol 2017;24: I37|-1380.

29. Pan A, Sun Q, Okereke OI, Rexrode KM, Hu FB. Depression and risk of stroke morbidity and mortality: A meta-analysis and systematic review. JAMA 201 1;306: I24I-I249.

30. Roest AM, Martens EJ, Jonge, de PJ, Denollet J. Anxiety and risk of incident coronary heart disease. J Am Coll Cardiol 2010;56: 38-46.

31. Lissaker CT, Norlund F, Wallert J, Held C, Olsson EM. Persistent emotional distress after a first-time myocardial infarction and its association to late cardiovascular and non-cardiovascular mortality. Eur J Prev Cardiol 2019;0: 1-9.

32. Chida $Y$, Steptoe A. The association of anger and hostility with future coronary heart disease: A meta-analytic review of prospective evidence. J Am Coll Cardiol 2009;53: 936-946.

33. Pogosova N, Saner H, Pederson SS, Cupples ME, McGee H. Psychosocial aspects in cardiac rehabilitation: From theory to practice. A position paper from the cardiac rehabilitation section of the European Association of Cardiovascular Prevention and Rehabilitation 
of the European Society of Cardiology. Eur Prev Cardiol 2015; 22: 1290-1306.

34. Wilkinson P. Myocardial infarctions: Risk factors, Emergency Management and Long-Term Health Outcomes. Nova Science Publishers, Inc, 20I4, 53-76.

35. Montfort van E, Denollet J, Vermunt JK, Widdershoven J, Kupper N. The tense, the hostile and the distressed: multidimensional psychosocial risk profiles based on the ESC interview in coronary artery disease patients - the THORESCl study. General Hospital Psychiatry 2017;47: 103-111.

36. Rozanski A, Blumenthal JA, Kaplan J. Impact of psychological factors on the pathogenesis of cardiovascular disease and implications for therapy. Circulation 1999;99: 2192-2217.
37. Mausner-Dorsch H, Eaton WW. Psychosocial work environment and depression: Epidemiologic assessment of the demand-control model. Am J Public Health 2000;90: 1765-1770.

38. Pizzi C, Santarella L, Bugiardini R. Epidemiology and the physiopathological link between depression and cardiovascular disease. IJC Metab Endoc 2014;5: 52-55.

39. Diene E, Fouquet A, Esquirol Y. Cardiovascular diseases and psychosocial factors at work. Arch Cardiovasc Dis 2012;105: 33-39.

40. Sparrenberger F, Cichelero FT, Scoli AM, Fonseca FP, Weiss G, Berwanger O, Fuchs SC, Moreira LB, Fuchs FD. Does psychosocial stress cause hypertension? A systematic review of observational studies. J Hum Hypertens 2009;23: I2-19. 